\title{
PREFACE TO THE PAPERBACK EDITION
}

IN THE YEARS since the original publication of The Longing for Total Revolution an epoch in political history has come to an end with the collapse of communism in Eastern Europe and the former Soviet Union. In coming years, the cooling of cold-war passions may create a better environment for understanding the especially intense and violent forms of social discontent that have characterized this epoch. But the demise of communism seems so far to have produced only a revival of simplistic and misleading theories about the nature of modern revolutionary sentiments, the most popular of which locates the origins of totalitarianism in the wild and wilful visions of modern philosophers such as Rousseau, Marx, and Nietzsche.

The Longing for Total Revolution attempts to replace these theories with a subtler and more accurate account of the connection between philosophic ideas and modern revolutionary sentiments. Although I reject theories about the philosophic origins of totalitarianism, I still believe that philosophers make an important contribution to the peculiar breadth and intensity of modern forms of social discontent. But I locate this contribution more in their new ways of thinking about what is wrong with our lives than in their new visions of a healthy social order.

The identification of the deeper reasons for our dissatisfaction with the world is one of the most influential activities undertaken by intellectuals. Everyone can find cause for dissatisfaction with the way things are. But it is primarily intellectuals_-from priests and philosophers to journalists and political organizers - who devote special efforts to explaining why the world contains these sources of dissatisfaction. Their efforts inspire new longings for 
social change by focussing our discontent on the deeper obstacles to human satisfaction that they uncover. Moreover, different understandings of these obstacles will inspire very different kinds of social discontent. The mystic who treats the world's impermanence as the primary reason for our dissatisfaction will not share the indignation against individuals and social institutions of those who long for a world without sin or exploitation. The Marxist who locates the obstacle to human satisfaction in a historically specific mode of social interaction will embrace worldly remedies to human suffering far more enthusiastically than will the Christian or Platonist who longs to transcend the human condition itself.

European philosophers such as Rousseau, Marx, and Nietzsche introduce and popularize a new perspective on the limitations of individuals and institutions, a perspective that tends to turn even relatively minor complaints into systematic problems that can be corrected only by a "total revolution" against the spirit of modern society. For, from this perspective, it is the "spirit" of modern individuals and institutions-the dehumanizing social ethos that shapes modern society as a whole-that accounts for our dissatisfaction with ourselves and the world. In The Longing for Total Revolution I try both to identify the philosophic innovations that ground this new understanding of the obstacles to human satisfaction and to show that, despite their many differences, a wide range of European philosophers and social critics share this understanding and the longings for social transformation that it inspires.

My genealogical arguments also support a critique of the call for total revolution issued by Marx and Nietzsche. They support such a critique by uncovering the unstated assumptions about freedom, nature, and history that lead Marx and Nietzsche to focus their discontent on the spirit of modern society. Once we identify and reflect upon these assumptions we must acknowledge, I argue, that the spirit of modern society, as they conceive of it, is an immovable obstacle to our satisfaction and that their goal of total revolution is a logical and practical impossibility.

In the wake of the collapse of communism one has to wonder, however, whether there remain any social theorists or revolutionaries against whom one might direct this critique. The last place 
one would look for traces of the longing for total revolution is among the highly conservative and defensive apparatchiks who cling to the communist legacy. And among radicals it has become fashionable, following the lead of French intellectuals, to scorn dreams of human emancipation. Many radical intellectuals, echoing Nietzsche and Foucault, now treat the attachment to morally elevated ideas of "humanity" - the purported "emancipatory subject" of world history-as a major source of mental and physical cruelty in the modern world.

But the Nietzschean echoes in the rhetoric of contemporary radicals make me wonder whether we really have turned the page on this chapter in intellectual history. In the final sections of The Longing for Total Revolution I try to show that Nietzsche's boasts about having overcome German philosophy and its discontents are premature and misleading. I argue there that while Nietzsche does rebel against the vision of humanity and historical progress he finds in the German philosophic tradition, he never abandons its obsession with the dehumanization of modern individuals and institutions. Nietzsche merely inverts the values bequeathed to him by his philosophic predecessors. In the end, he persists in their efforts to correct the decline of humanity in the modern world, despite his violent rejection of their more "humanistic" understanding of the truly human form of life.

Of course, the Nietzsche celebrated by contemporary radicals cuts a very different figure from the philosopher described in The Longing for Total Revolution. Theirs is the playful, anti-essentialist Nietzsche who gleefully informs us that there are no facts, only interpretations-the Nietzsche whom one invokes in achingly cute titles such as Exceedingly Nietzsche or "Reading Derrida Reading Heidegger Reading Nietzsche" -rather than the deeply discontented philosopher who strives so hard to confront and overcome the burdens of two thousand years of Christian culture. For them Nietzsche is the joyful founder of the postmodern age, rather than the desperate and self-defeating promoter of a cultural revolution against the spirit of modernity. Hence even if I am correct in my interpretation and critique of Nietzsche, it seems that postmodernist radicals have cheerfully abandoned the very elements of his 
thought upon which I focus my attention. For this reason, they may seem unlikely to share his longings for total revolution.

Nevertheless, there remains at least one element in the rhetoric of postmodernist radicals that makes me suspect that they have not entirely abandoned the philosophic sources of Nietzsche's social discontent. In spite of the postmodernists' repeated attacks on essentialism and foundationalism, in spite of all their scorn for historical "meta-narratives," there is one meta-narrative that serves as a philosophical foundation for all postmodernist thinking: that something called "modernity" exists and has shaped modern individuals and institutions, even if it is now beginning to lose its grip on us. Postmodernist radicals may have abandoned Marx's "fetishism of commodities," but they still cling to a fetishism of modernities. That the obsession with modernity is, to a certain extent, a fetish, is something that I try to demonstrate in The Longing for Total Revolution. It is a fetish, I argue, because it treats historical epochs such as "modernity" as if they were real dividers and shapers of human behaviour, rather than as intellectual constructs. Historical epochs, such as modernity or classical antiquity, are constructs that we design in order to highlight, through historical comparison, distinctive elements of any set of practices and institutions. With the "fetishism of modernities" these conceptual constructs come back to haunt us as the real-world obstacles to our goals. In this regard postmodernists differ from Nietzsche and the other social critics I study only in their belief that we have somehow leapt-quietly, without any revolutionary upheavals-to the other side of the real-world barrier created by modernity.

But little has changed in the world to justify claims about the advent of a "postmodern condition" - except for the ways in which postmodernists have changed their minds about the universalistic goals that once inspired them. While we may be able to escape "modernity" - i.e., the intellectual construct-by changing our minds, we cannot so easily escape the new social practices and institutions that led earlier social critics to construct the concept of modernity in the first place. When postmodernists wake up to this fact, they will have to confront all over again the distinctive social conditions that the concept of modernity was developed to high- 
light. At that time, some postmodernists may discover that postmodernism stands, ironically, for reconciliation with modernity, for the abandonment of the intense dissatisfaction with the spirit of modern society that characterizes the works of so many "modernist" artists and intellectuals. Others, however, may discover that they continue to be just as dissatisfied with modern individuals and institutions as Rousseau, Marx, and Nietzsche. When they make this discovery, we may witness-along with the predictable calls for a "new realism" or a "new materialism" - a new wave of the longing for total revolution. For this reason, among others, my study may continue to provide critical as well as genealogical arguments about distinctively modern forms of social discontent. 
